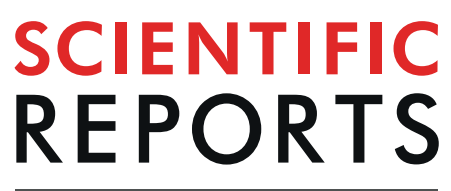

natureresearch

\title{
OPEN
}

Published online: 21 January 2020

\section{Author Correction: Biosurfactant Production by Lactic Acid Bacterium Pediococcus dextrinicus SHU1593 Grown on Different Carbon Sources: Strain Screening Followed by Product Characterization}

\section{Abouzar Ghasemi, Marzieh Moosavi-Nasab, Payam Setoodeh, Gholamreza Mesbahi \& Gholamhossein Yousefi}

Correction to: Scientific Reports https://doi.org/10.1038/s41598-019-41589-0, published online 27 March 2019

In this Article, the legend of Figure 5 is incorrect:

"Stability study of BS derived from P. dextrinicus SHU1593 at different pH values. Results are expressed as mean \pm standard deviations of values from triplicate experiments."

should read:

"Stability study of BS derived from $P$. dextrinicus SHU1593 at different $\mathrm{pH}$ values. Results are expressed as mean \pm standard deviations of values from triplicate experiments."

Additionally, this Article contains a typographical error in the Author Contributions section.

“M.M.N.; Advisers: P.S., G.M., G.Y.; Writing draft: A.G.; Writing review, editing and revision: A.G., M.M.N., P.S.; Funding acquisition: M.M.N.; Software: A.G., M.M.N., P.S.; Data analysis: A.G., M.M.N., P.S.”

should read:

"Supervisor: M.M.N.; Advisers: P.S., G.M., G.Y.; Writing draft: A.G.; Writing review, editing and revision: A.G., M.M.N., P.S.; Funding acquisition: M.M.N.; Software: A.G., M.M.N., P.S.; Data analysis: A.G., M.M.N., P.S.” 
(c) (i) Open Access This article is licensed under a Creative Commons Attribution 4.0 International License, which permits use, sharing, adaptation, distribution and reproduction in any medium or format, as long as you give appropriate credit to the original author(s) and the source, provide a link to the Creative Commons license, and indicate if changes were made. The images or other third party material in this article are included in the article's Creative Commons license, unless indicated otherwise in a credit line to the material. If material is not included in the article's Creative Commons license and your intended use is not permitted by statutory regulation or exceeds the permitted use, you will need to obtain permission directly from the copyright holder. To view a copy of this license, visit http://creativecommons.org/licenses/by/4.0/.

(C) The Author(s) 2020 